\title{
Short report on probable case of Caspian Gull predation on migrating swallows observed at first time
}

\author{
Klaudia LitwiniaK ${ }^{1}$, Marcin PrZYMENCKI ${ }^{1 *} \&$ Damian CelińSKI ${ }^{2}$
}

Received: December 14, 2019 - Revised: February 10, 2020 -Accepted: February 11, 2020

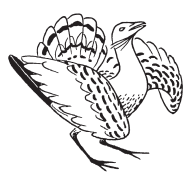

Litwiniak, K., Przymencki, M. \& Celiński, D. 2020. Short report on probable case of Caspian Gull predation on migrating swallows observed at first time. - Ornis Hungarica 28(1): 181-184. DOI: $10.2478 /$ orhu-2020-0012 tica). The bodies of swallows were fresh and torn with traces of bill. We assume that swallows might have been in weak condition and hunted by gulls. They also could die because of bad weather conditions and hypothermia, fell into the water and then were taken. However, to our knowledge, it was the first mass event of feeding on migrating birds by Caspian Gull.

Keywords: Larus cachinnans, passerine, feeding on birds, predator

Összefoglalás A 2019. évi költési időszakban a délnyugat-lengyelországi Mietków Reservoir területén 52, többségében füsti fecske (Hirundo rustica) tetemet találtunk egy sztyeppi sirály (Larus cachinnans) kolóniában. A fecske tetemek frissek voltak, tépések nyomaival. A fecskék valószínúleg legyengült állapotban voltak, ezért estek a sirályok áldozatául. Ugyanakkor a rossz időjárási viszonyok és a kihülés, sőt a vízbeesés is a pusztulásukhoz vezethetett, ami után a sirályok összeszedhették a tetemeket. Azonban jelen tudásunk szerint ez az első tömeges eset, amikor vonuló madarak tetemein táplálkozó sztyeppi sirályokat figyeltek meg.

Kulcsszavak: sztyeppi sirály, énekesmadár, madártetemek, zsákmányszerzés

\footnotetext{
${ }^{1}$ Poleska 41/20, 51-354 Wroctaw, Poland

${ }^{2}$ Najświętszej Maryi Panny 46/27, 42-217 Częstochowa, Poland

*corresponding author: marcin.przymencki@wp.pl
}

Gulls (Larinae) have an opportunistic feeding ecology. Obtaining food is done in many ways, among others through predation, scavenging and kleptoparasitism (Avdanin et al. 1998). There are numerous studies about depredation of birds by large gulls. Great Blackbacked Gulls Larus marinus have been known to kill swimming Slavonian Grebe Podiceps auritus and Lesser Scaup Aythya affinis (Mansueti 1961). Herring Gulls Larus argentatus were observed during attacking and killing sick birds, for example Curlew Numenius arquata, American Wigeon Anas americana or Little Gull Hydrocoleus minutus (Tinbergen 1953, Mansueti 1961, Macdonald \& Mason 1973). There are also a number of reports of large gulls attacking migrants in flight over the sea, mostly passerines (Colston et al. 1959, Dyck 1969, Macdonald \& Mason 1973, Dierschke 2001). Dierschke (2001) reported that Starlings Sturnus vulgaris and thrushes Turdus spp. were the most often found in large gulls' pellets on Helgoland Island. He also found bones of such species as Dunnock Prunella modularis, Robin Erithacus rubecula, Pied Wagtail Motacilla alba and Common Whitethroat Sylvia 
communis. Macdonald and Mason (1973) observed Herring Gulls attacking and killing migrating Starlings, Blackbirds Turdus merula and Redwings Turdus iliacus on the sea. Studies show that passerines form a part of gulls' diet mainly during their migration (Dierschke 2001). Because of being exhausted and flying over open, unsheltered space, migrating birds might be captured in easy way by gulls. Various methods of capture have been observed, among others when victim was forced into the sea by continual harrying or it was knocked into the water by the gulls' beating wings or feet (Macdonald \& Mason 1973).

Caspian Gull Larus cachinnans is a large species feeding mainly on fishes on the western edge of its breeding area (Skórka \& Wójcik 2008, Gwiazda et al. 2011). There is different situation in its core range, for example in Crimea (Kiselev 2009) and Caspian Sea basin (Avdanin et al. 1998), where gulls usually feed on rodents, like Little Ground Squirrel Spermophilus pygmaeus. Predation on other vertebrates by this species, especially birds, seems to be uncommon (Gwiazda et al. 2011) and there has not been described any case of hunting on passerines so far. This paper presents the first mass event of feeding on migrating birds by Caspian Gull.

On the $17^{\text {th }}$ May 2019 we observed many dead swallows in or close to nests in a breeding colony of Caspian Gull. They were mainly Barn Swallows Hirundo rustica and a few House Martins Delichon urbicum (Figure 1). We counted 52 dead swallows on three islands but 39 of them were found on one island. The bodies of swallows were torn with traces of bill ( $F i$ gure 2). We also found one Barn Swallow with wings firmly attached to the body and glued feathers (Figure 3). It suggests that this one was eaten and spat out by adult gull or chick. All of swallows' bodies were fresh and probably laid there up to 2 days. Number of dead swallows presumably was higher as swallow's parts of skin with feathers or single feathers were abundant in the vicinity of some gull's nests.

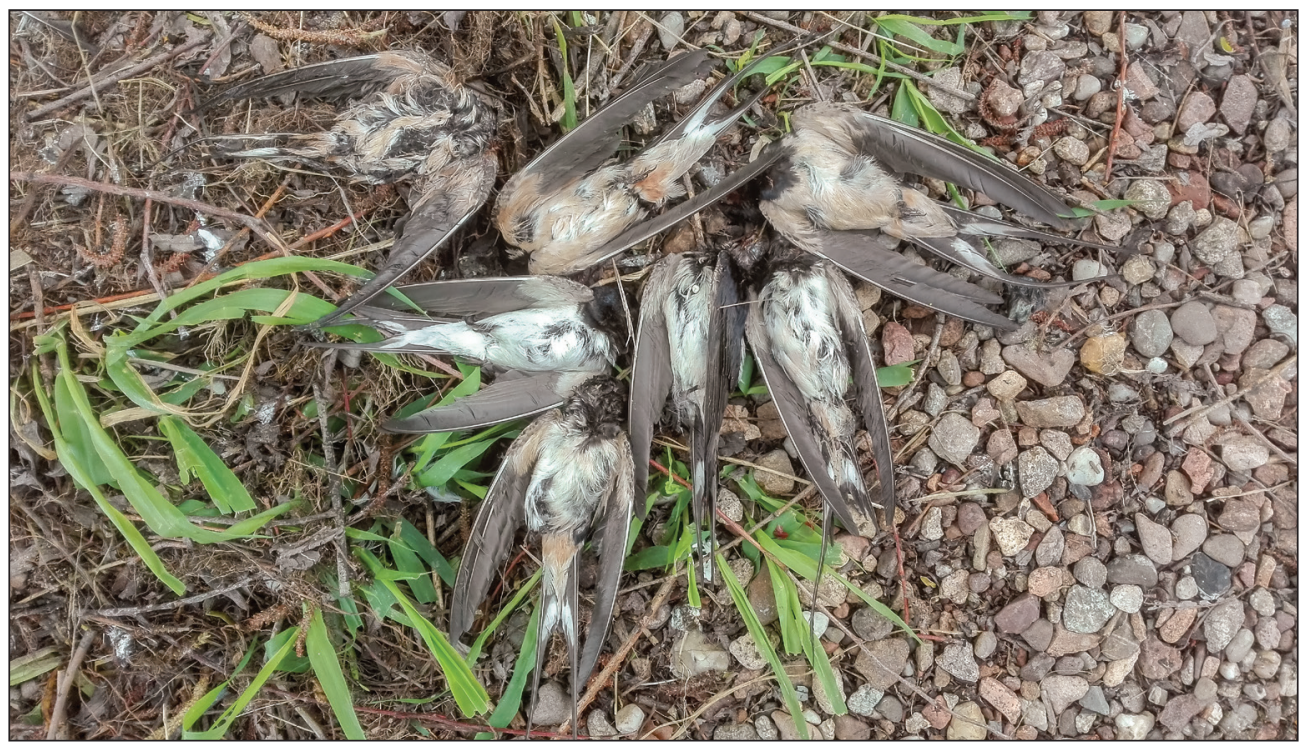

Figure 1. Dead Barn Swallows and House Martin in this colony

1. ábra Füsti fecske és molnárfecske tetemek a vizsgált kolóniában 


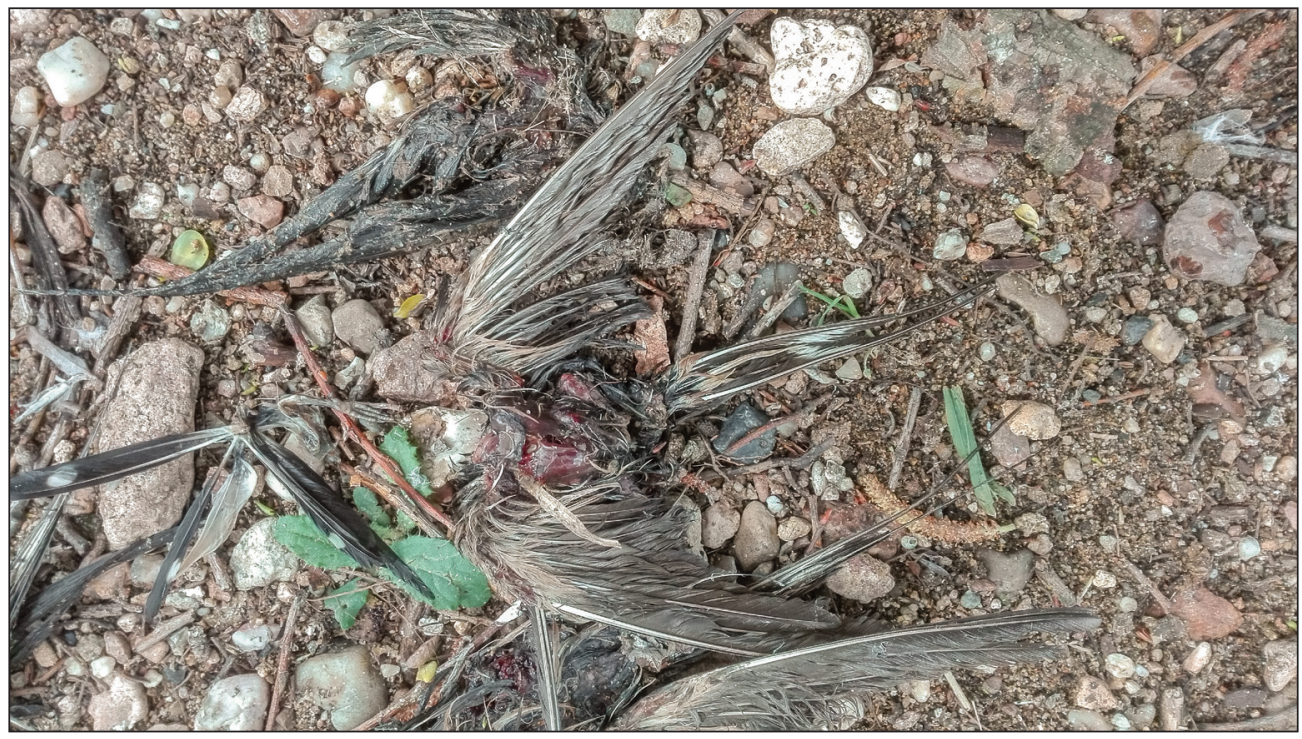

Figure 2. Barn Swallow's body torn with traces of bill

2. ábra Füsti fecske teteme tépések nyomaival

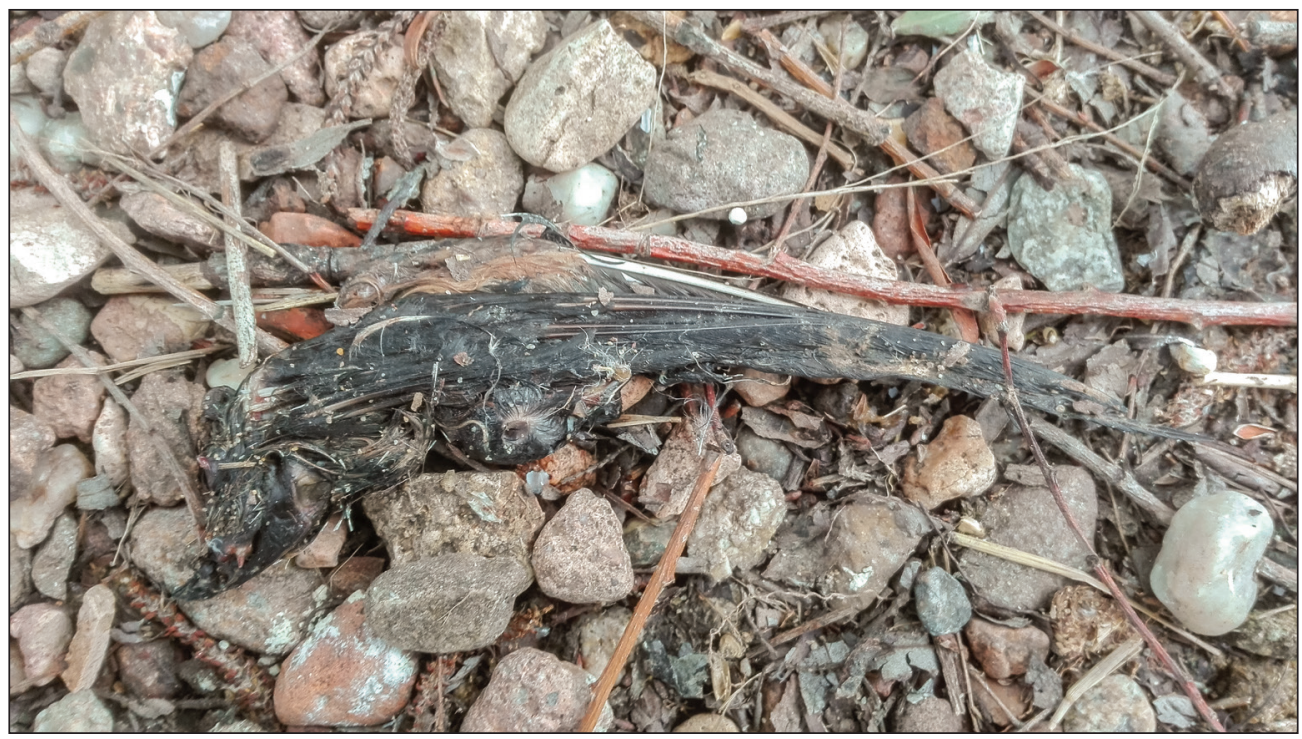

Figure 3. Barn Swallow with wings attached to the body and glued feathers

3. ábra Füsti fecske testhez simuló szárnyakkal, összeragadt tollakkal

This Caspian Gulls colony is located at inland Mietkow Reservoir (50 57'35.2'N $\left.16^{\circ} 37^{\prime} 19.6^{\prime \prime} \mathrm{E}\right)$ in SW Poland. It is a dam reservoir on the Bystrzyca river, nearly the Sudeten Mountains. Caspian Gulls usually nest there on one big island with grass and other vegetation up to $1 \mathrm{~m}$ high. This year they chose to nest nine small islands covered by willows. There were 3-50 pairs per island. The reservoir is foraging place to many species of birds 
when migration is going, for example waders and geese. During spring migration, there are also thousands of swallows. The most numerous species is the Barn Swallow, but there are many House Martins and Sand Martins too.

As swallows have fast and maneuverable flight and seem not to be easy-to capture prey for large gulls, we suppose that in this case birds might have been in weak condition and Caspian Gulls actively hunted them. However, observation of Glaucous-winged Gull Larus glaucescens capturing singing males of Fox Sparrow Passerella iliaca at their breeding grounds, not during migration (Nietlisbach et al. 2014), proves that large gulls are able to catch small passerines even in good physical condition. Another explanation might be that swallows were already dead in the moment they were captured by gulls. They could die because of bad weather conditions and hypothermia, fell into the water and then were taken. If so, other dead swallows would float on the water surface or would be found in other places of colony but that was not the case. Probably a few Caspian Gulls specialized in catching swallows during their migration and it happens every spring when gulls are in breeding colony. It is also possible that it was one-time case when some gulls followed their neighbours catching swallows. Both hypothesis are supported by the fact that $75 \%$ victims were found on only one island and 7 bodies laid at only one nest. As shows only existing study on foraging strategy of Caspian Gull, cases of preying on birds by this species have been very rare and consider three observations where Coot Fulica atra and Moorhen Gallinula chloropus chicks were killed (Skórka \& Wójcik 2008). Our findings might suggest that this species can take advantage of migrating passerines through mainland as an additional food source, likewise their relatives, Herring Gulls, hunting on birds offshore (Macdonald \& Mason 1973). Also, preying on birds might be more widespread in Caspian Gulls than it has been reported so far.

\section{References}

Avdanin, V. O., Viksne, Y. A., Zubakin, V. A., Kishchinsky, A. A., Litvinenko, N. M., Lobkov, E. G., Nechaev, V. A., Firsova, L. V., Flint, V. E. \& Yudin, K. A. 1998. Birds of the USSR. Gulls. - Nauka, Moscow (in Russian) Dierschke, V. 2001. Large gulls as predators of passerine landbirds migrating across the southeastern North Sea. - Ornis Svecica 11: 171-180.

Gwiazda, R., Bukaciński, D., Neubauer, G., Faber, M., Betleja, J., Zagalska-Neubauer, M., Bukacińska, M. \& Chylarecki, P. 2011. Diet composition of the Caspian Gull (Larus cachinnans) in inland Poland: effects of breeding area, breeding stage and sympatric breeding with Herring Gull (Larus argentatus). - Ornis Fennica 88: 80-89.

Kiselev, F. A. 2009. Agricultural value of the Caspian Gulls Larus argentatus cachinnans. - Russian Bird Watch 18: 1595-1603. (in Russian)

Macdonald, S. M. \& Mason, C. F. 1973. Predation of migrant birds by gulls. - British Birds 66: 361-363.

Mansueti, R. J. 1961. Waterfowl predation by and records of the Great Black-backed Gull in Chesapeake Bay during winter and spring. - Chesapeake Science 2(1-2): 102-104.

Nietlisbach, P., Germain, R. R. \& Bousquet, C. A. H. 2014. Observations of Glaucous-winged Gulls preying on passerines at a Pacific Northwest colony. - The Wilson Journal of Ornithology 126(1): 155-158. DOI: 10.1676/13-077.1

Skórka, P. \& Wójcik, J. D. 2008. Habitat utilisation, feeding tactics and age-related feeding efficiency in the Caspian Gull Larus cachinnans. - Journal of Ornithology 149(1): 31-39. DOI: 10.1007/s10336-007-0208-3

Tinbergen, N. 1953. The Herring Gull's World. - Frederick A. Praeger, Inc. London 